\title{
In search for a greater pluralism of theories and methods in governance research
}

Praveen Kumar \& Alessandro Zattoni

A few years ago, Durisin and Puzone (2009) undertook a major effort to map the intellectual structure of governance research with the ultimate aim of understanding the level of maturity of corporate governance as a discipline. Their bibliometric analysis of more than 1,000 publications shows that corporate governance research is characterized by both the use of agency theory as dominant theoretical lens, and empirical samples from one country, typically the US and to a less

extent the UK. In such a context, the authors claim that CGIR has the distinction of significantly contributing to the maturation of corporate governance as a discipline by providing an intellectual space where authors from different disciplines and geographic areas can dialog and build on others' research. At the same time, Durisin and Puzone encouraged CGIR to take further initiatives to move the debate beyond its current theoretical and geographical limits. Later, Zattoni and van Ees (2012) supported and extended this view by analyzing papers published in CGIR during the period 2008-10. They show that a large majority of studies explore governance issues related to control and monitoring, build hypotheses using an agency theoretical perspective, collect empirical data about one single country (in most of the cases a liberal market economy), follow an explanatory theory testing methodological approach. Based on this review, they invited governance scholars to broaden the theoretical and methodological scope of their researches in order to increase our understanding of global corporate governance phenomena. In particular, they encouraged scholars to develop studies that: (i) adopt complementary or alternative theories to agency theory; (ii) explore the interaction among governance mechanisms; (iii) collect longitudinal data in order to capture the evolution of governance practices and national institutions along the time; and, (iv) analyze governance phenomena in relatively unexplored countries and/or in cross-country research projects taking into account the institutional forces developed at the national level.

Given this background, the journal is striving to publish papers that fulfill these expectations. The four papers published in this issue are all nice examples of studies broadening our understanding of corporate governance phenomena by going beyond agency theory as a single lens and adopting a methodological pluralism (Judge, 2008). In particular, the first study provides not only a more systematic understanding of the out- or under-performance of listed 
family firms versus other types of firms, but also explores the role of firm strategies in the family control - firm performance relationship. We particularly appreciate both the use of a robust metaanalysis technique on studies using samples of US family listed companies (see also Carney, Van Essen, Gedajlovic and Heugens, 2013, for private family firms), and the search for the effect of strategic mediating variables on family control-performance relationship (see also Zattoni, Gnan, Huse, 2013 on the mediating role of board processes and effectiveness). The second and the third studies follow a qualitative approach (e.g., McNulty, Zattoni \& Douglas, 2013; Zattoni, Douglas \& Judge, 2013) and provide interesting and relevant evidence on the growing literature on board processes and effectiveness (e.g., Kumar and Sivaramakrishnan, 2008; McNulty, Florackis \& Ormrod, 2013; Zona \& Zattoni, 2007). These studies are noteworthy because they explore two board characteristics, namely, directors' nationality and language and directors' identification, that are relatively understudied in the literature. They then examine the impact of these characteristics on board processes and effectiveness in Scandinavian countries. The special merit in fourth paper is to develop a sociopolitical perspective on the diffusion of shareholder value orientation and to test hypotheses on a longitudinal sample of the largest listed companies in the Netherlands. In sum, all papers make significant efforts to advance our theoretical, empirical, and practical knowledge of corporate governance issues around the world.

More in depth, the first study published in this issue contributes to the literature by addressing an important topic in corporate governance and family business research: whether publicly listed family firms outperform other types of companies. To advance our knowledge on this issue, Van Essen, Carney, Gedajlovic, and Heugens develop hypotheses on the relative performance of listed family firms versus listed nonfamily firms. In addition, the study explores the mediating role of strategic choices (i.e. diversification, internationalization, and leverage) in the family control - firm performance relationship. Here, they complement a growing literature that examines strategic participation in international markets by family-owned or controlling shareholder dominated companies and the subsequent impact on their corporate governance (e.g., Kumar and Ramchand, 2008). The paper also contributes to the literature that relates ownership structure to financial strategy, such as the choice of leverage (Aslan and Kumar, 2012, 2014). Finally, the authors investigate the mediating role of both control enhancing-mechanisms and firm strategies in the negative relationship between successor control and performance. To address these objectives, the authors analyze a sample of 74 primary studies on listed family 
firms in the US context. The results of the meta-analysis show that family firms outperform nonfamily firms. Furthermore, the performance of family-controlled firms is mediated significantly by firm strategies. In particular, successor-controlled family firms underperform primarily because of their more conservative strategies.

The second paper by Piekkari, Oxelheim, and Randøy explores how language diversity affects work processes in the boardroom. This is both an underexplored and a relevant issue as there is a general call for more diversity in the boardroom, including diversity of nationalities. To examine this issue, they do a multiple case study of corporate boards of nine multinational corporations located in four Nordic countries. The results show that, despite some similarities among Nordic languages and cultures, the switch to English generates an impoverishment of discussions - and sometimes silence - in all boards that did not prepare adequately for the switch to a common (foreign) language. This is mostly due to the difficulties of some board members to contribute actively to board debate, and particularly to express their disagreements, when they have to speak in a non-native language. The lack of adequate command of English by some board members (especially the employee representatives) negatively affects board processes and raises concerns about the growing of internationalization of board members in presence of codetermination.

The third study by Melkumov, Breit and Khoreva explores the influence of directors' social identification on their involvement in board tasks. The theoretical development in this study builds on the Hillman, Nicholson and Shropshire (2008) conceptual model on the relationships between directors’ identification and board monitoring and resource provision tasks. In particular, the authors examine the influence of directors' identification with the organization, shareholders, and customers on board monitoring and resource provision tasks. They test empirically these hypotheses using a questionnaire survey with answers from 92 large Finnish industrial companies. The results show that directors' organizational identification influences positively board involvement in both tasks. Meanwhile, shareholder identification exerts a negative influence on board strategic participation, but has positive impact on top management monitoring. And customer identification has a positive impact on resource provision tasks. As such, the study provides a contribution to board research by showing that organizational identification matters for board effectiveness. 
The fourth study by Bezemer, Zajac, Naumovska, van den Bosch and Volberda examines the diffusion of shareholder value orientation (SVO) among listed companies in the Netherlands. The paper builds its theoretical development on literature on the diffusion of contested organizational practices, i.e., practices opposed by some actors operating according to a previous logic. The authors develop hypotheses about the influence of power of both independent and Anglo-American institutional investors on firm espousal to SVO, and the change of power of both types of institutional investors on performance consequences for firms espousing to SVO. The authors test their hypotheses using longitudinal data (1992-2006) from the largest 100 listed companies of a small stakeholder-oriented country, i.e., the Netherlands. The results show a negative relationship between SVO espousal and performance. The analysis highlights the attenuation of this negative effect under both greater SVO alignment among shareholders and greater commitment to SVO.

\section{References}

Aslan, H. \& P. Kumar, 2012, Strategic ownership structure and the cost of debt. Review of Financial Studies, 25, 2257-2299.

Aslan, H. \& P. Kumar, 2014, National governance bundles and corporate agency costs: A crosscountry study. Corporate Governance: An International Review, 22, 23-251.

Carney, M., Van Essen, M., Gedajlovic, E.R. \& Heugens, P.P.M.A.R. 2013. What do we know about private family firms? A meta-analytical review. Entrepreneurship Theory and Practice. doi:10.1111/etap.12054.

Durisin, B. \& Puzone, F. 2009. Maturation of corporate governance research, 1993-2007: An assessment. Corporate Governance: An International Review. 17(3): 266-291.

Hillman, A., Nicholson, G. \& Shropshire, C. 2008. Directors' multiple identities, identification and board monitoring and resource provision. Organization Science, 19: 441-456.

Judge, W. Q. 2008b. Methodological Pluralism. Corporate Governance: An International Review, 16(4): ii.

Kumar, P. \& Sivaramakrishnan, K. 2008. Who monitors the monitor? The effect of board independence on executive compensation and firm value. Review of Financial Studies, 21, 1371-1401. 
Kumar, P. \& Ramchand, L. 2008. Takeovers, market monitoring, and international corporate governance. Rand Journal of Economics, 39, 850-874.

McNulty, T., Florackis, C., \& Ormrod, P. 2013. Boards of Directors and Financial Risk during the Credit Crisis. Corporate Governance: An International Review, 21(1): 58-78.

McNulty, T., Zattoni, A., \& Douglas, T., 2013. “Developing corporate governance research through qualitative methods: a review of previous studies”, Corporate Governance: An International Review, 21(2): 183-198

Zattoni, A., Gnan, L., \& Huse, M. 2013. Does family involvement influence firm performance? Exploring the mediating effects of board processes and tasks. Journal of Management, doi:10.1177/0149206312463936

Zattoni, A., Douglas, T. \& Judge, W. 2013. Developing corporate governance theory through qualitative research. Corporate Governance: An International Review, 21(2): 119-198.

Zattoni, A. \& Van Ees, H., 2012. "How to contribute to the development of a global theory of corporate governance? Reflections from submitted and published articles on CGIR", Corporate Governance: An International Review, 20 (1): 106-118

Zona, F. \& Zattoni, A. 2007. Beyond the black box of demography: Board processes and task effectiveness within Italian firms. Corporate Governance: An International Review, 15: 852864. 